\title{
DO ORTHOPTIC EXERCISES HAVE ANY INFLUENCE ON CHILDREN AND ADOLESCENTS DIAGNOSED WITH CONVERGENCE INSUFFICIENCY AND ATTENTION DEFICIT/HYPERACTIVITY DISORDER?
}

\author{
Barbara Dawidowsky ${ }^{1}$, Branimir Cerovski ${ }^{2}$, Aleksandra Klobučar ${ }^{1}$ and Krsto Dawidowsky ${ }^{2}$ \\ ${ }^{1}$ Zagreb Children's Hospital, Zagreb, Croatia; \\ ${ }^{2}$ Zagreb University Hospital Centre, Zagreb, Croatia
}

\begin{abstract}
SUMMARY - The aim was to determine whether improvement of near point of convergence (NPC) and binocular vision after orthoptic exercises had any impact on children and adolescents diagnosed with attention deficit/hyperactivity disorder (ADHD) and convergence insufficiency (CI). In this clinical trial, 50 children and adolescents aged 6 to 18 years diagnosed with ADHD and CI received orthoptic therapy that included home-based exercises (pencil push-ups and stereograms) and office-based therapy on synoptophore. Binocular vision and NPC were measured before, during and after therapy. Study subjects showed significant improvement $(\mathrm{p}<0.05)$ in NPC and binocular vision after orthoptic exercises. We found statistically significant correlation between stereovision improvement (Lang I) and near point of convergence, suggesting that improvement of binocular function is possible in children with ADHD and CI. Our results showed that NPC enhancement improved stereovision in patients with ADHD. Since progress of binocular function has positive effect on near work and diminishes visual symptoms in children and adolescents with ADHD and CI, it might be reasonable to suppose that orthoptic therapy helps these children improve concentration as well. Further studies are needed to determine whether it might have positive impact on attention.
\end{abstract}

Key words: Attention deficit disorder with hyperactivity; Ocular motility disorders; Vision, binocular

\section{Introduction}

Attention deficit/hyperactivity disorder (ADHD) is a neurodevelopmental disability estimated to affect between $3 \%$ and $12 \%$ of the school age population ${ }^{1,2}$. ADHD is a clinical diagnosis and diagnostic criteria are defined in the Diagnostic and Statistical Manual of Mental Disorders, Fifth Edition (DSM-V) released in May 2013 by the American Psychiatric Association $^{3,4}$.It is still not known exactly what causes ADHD, but scientific evidence suggests that the disorder is ge-

Correspondence to: Barbara Dawidowsky, $M D$, Zagreb Children's Hospital, Department of Neurosurgery, ENT and Ophthalmology, Klaićeva 16, HR-10000 Zagreb, Croatia

E-mail: barbara.dawidowsky@zg.t-com.hr

Received October 4, 2018, accepted October 30, 2018 netically transmitted in many cases and results from chemical imbalance or deficiency in certain neurotransmitters that help the brain regulate behavior ${ }^{5-7}$. The primary features associated with ADHD syndrome are inattention, hyperactivity and impulsivity, and according to these main features, ADHD syndrome is now divided into three subtypes, as follows: predominantly hyperactive-impulsive type, predominantly inattentive type, and predominantly combined type ${ }^{8,9}$.

Regardless of the type of disorder, children will have significant symptoms of all three characteristics and these symptoms seriously affect the life of the child, family, school and social relationship. Considering visual symptoms, they often complain of disturbance in reading and writing, blurred vision, double 
vision, losing rows, difficulty in concentrating, headaches and eyestrain. Children and adolescents who fulfill the criteria for the diagnosis of ADHD often have several other different psychiatric disorders (psychiat$\mathrm{ric} /$ neurodevelopmental comorbidity). It is supposed that some connection exists between ADHD and these comorbid disorders, even in common organic and psychosocial etiopathogenesis. In the treatment of children diagnosed with ADHD, a multimodal approach with combined medical and psychosocial treatment has been most effective.

Convergence insufficiency $(\mathrm{CI})$ is a common binocular vision disorder that affects $4 \%-8 \%$ of the population ${ }^{10-12}$. It was first described by von Graefe in 1855 , and is often associated with a variety of symptoms such as headaches, eyestrain, blurred vision, diplopia, reading slowly, losing rows, and difficulties in concentrating while doing work at near ${ }^{13,14}$. CI is characterized by patient inability to converge the eyes as the object moves from distance to near and/or the inability to maintain the near point of convergence (NPC) ${ }^{15}$. It leads to the loss of binocular vision and results in difficulties while reading and writing. Over years, various definitions have been used in the diagnosis of CI, but an NPC $<6 \mathrm{~cm}$ or exophoria greater at near are usual clinical findings in most studies ${ }^{16-18}$. CI is a treatable condition using orthoptic exercises that increase the range of fusion convergence ${ }^{19-24}$. In 1999, Birnbaum et al. reported on the first controlled trial documenting that vision therapy was effective in the management of $\mathrm{CI}$ in adults ${ }^{25}$. In 2005, Rawstron et al. concluded that the only significant use of eye exercises was in the treatment of $\mathrm{CI}^{26}$. However, there has been a lack of consensus regarding the most effective treatment. Various therapeutic options are available, e.g., passive treatment with base in prism reading glasses, and active treatments such as pencil push-ups, stereograms, office-based orthoptic therapy and home computerized therapy ${ }^{20,27-30}$. The lack of consensus may be partly caused by considerable differences in terms of cost, ease of implementation and availability of these treatments in various countries.

Having noticed that many of the patients diagnosed with ADHD complained of various visual symptoms, they were subjected to ophthalmologic evaluation. Careful orthoptic examination revealed that some of them had subnormal binocular vision and receded NPC that pointed to symptomatic CI.
Since the first published study reporting on the connection of $\mathrm{CI}$ and $\mathrm{ADHD}^{31}$, only few studies have investigated how visual function training affects children with $\mathrm{ADHD}^{32,33}$.

As some of the visual symptoms of CI and patients with ADHD are very similar and may overlap, our aim was to treat $\mathrm{CI}$ in children diagnosed with both ADHD and CI and find out whether orthoptic therapy that successfully treats CI and simultaneously improves binocular function had any influence on those children as well. We were concerned whether children with ADHD would be able to perform such exercises successfully, since orthoptic therapy requires a lot of attention and concentration; however, first results showed that our patients were capable to perform short home exercises and office based therapy resulting in $\mathrm{CI}$ improvement.

\section{Subjects and Methods}

\section{Ethics}

All subjects participated with their parents who signed a written consent and the study was conducted according to the Declaration of Helsinki. All participants were informed on the details of the study. No objections were raised by the School of Medicine, University of Zagreb.

Participants were recruited from Department of Child and Adolescent Psychiatry, Zagreb Children's Hospital and diagnosis of ADHD was confirmed by a child psychiatrist according to the diagnostic criteria based on DSM-IV. Upon verifying ADHD, complete ophthalmologic evaluation was performed particularly examining binocular vision and revealing the presence of CI by measuring the NPC. CI was found in 62 of 172 (35.6\%) patients diagnosed with ADHD and examined at our Ophthalmologic Department. They were considered proper candidates for our study. Due to various reasons, 12 of them dropped-out, and at the end 50 children entered our trial. The major eligibility criteria were receded NPC $>6$, low fusion range measured with synoptophore (fusion range $<5$ ) or subnormal stereovision measured with stereo tests (Lang I and II and Titmus tests) and synoptophore. Exclusion criteria were some other psychiatric condition, history of past ocular treatment, best corrected visual acuity (BCVA) less than 0.8 on both eyes, refractive error $\leq+/-2.00 \mathrm{dsph}$ and $\leq+/-0.75 \mathrm{dcyl}$. If orthoptic exami- 
nation revealed any abnormality of binocular vision, such as manifest strabismus, exophoria $>6^{\Delta}$ or esophoria $>1^{\Delta}$, any vertical deviation and anisometropia, participants were excluded too.

\section{Examination procedures}

Eligibility testing included BCVA at distance, CI diagnosed by measuring NPC with Royal Air Force (RAF) ruler at least three times and the mean value recorded, binocular tests performed using Lang I and Lang II stereotests, and Titmus test. Fusion range was measured with synoptophore, cycloplegic refraction was measured and ocular health evaluation was performed.

Therapy for CI lasted for 9 months on average and consisted of home therapy including pencil push-ups and stereogram exercises twice a day and office-based orthoptic therapy on synoptophore (10 visits) at Department of Ophthalmology, ENT and Neurosurgery, Zagreb Children's Hospital.

The pencil push-ups procedure uses a pencil as target, which must be moved towards the nose as close as possible while trying to keep the target single and clear. Furthermore, the participants were advised not only to see the pencil tip as single at the nearest possible distance but also to maintain it as single for at least 10 seconds (convergence sustenance). Participants were instructed to perform the pencil push-ups twice a day, 6 to 10 times for approximately 5 minutes at a time. They were also instructed how to perform stereogram exercises (asked to achieve fused central image of the picture on the card) twice a day at least 6 times. Parents were asked to perform pencil push-ups with smaller children and were called at least once a week to be reminded of the importance of compliance. They were also instructed to regularly supervise and ensure that their child was carrying out the procedure correctly.

\section{Results}

A total of 50 participants, age range 6-18 years $(\mathrm{M}=10.26$, SD 2.78) met the inclusion/exclusion criteria and were analyzed. They all were administered orthoptic therapy for nine months on average. NPC, binocular vision (Lang I and II tests, and Titmus test) and fusion range on synoptophore were measured before therapy, and three and six months after the begin-
Table 1. Descriptive data on NPC, stereo tests (Lang I, Lang II, Titmus test) and synoptophore at first visit

\begin{tabular}{|l|l|l|}
\hline Variable & M (SD) & TR (min, max) \\
\hline NPC & $11.16(3.431)$ & $15(4-19)$ \\
Lang I & $1.62(0.878)$ & $3(0-3)$ \\
Lang II & $2.04(0.699)$ & $3(0-3)$ \\
Titmus test & $2.24(0.797)$ & $3(0-3)$ \\
Synoptophore & $11.14(6.395)$ & $32(0-32)$ \\
\hline
\end{tabular}

$\mathrm{NPC}=$ near point of convergence measured in centimeters; Lang I and II = measures ability to see $0 / 3,1 / 3,2 / 3$ or $3 / 3$ figures; Titmus test $=$ measures ability to see $0 / 3,1 / 3,2 / 3$ or $3 / 3$ figures; synoptophore $=$ measures fusion span in degrees; $\mathrm{TR}=$ total range; $\mathrm{M}=$ mean; $\mathrm{SD}=$ standard deviation

Table 2. Descriptive data on NPC, stereo tests (Lang I, Lang II, Titmus test) and synoptophore at second visit

\begin{tabular}{|l|l|l|}
\hline Variable & M (SD) & TR (min, max) \\
\hline NPC & $6.32(2.817)$ & $11(3-14)$ \\
Lang I & $2.60(0.639)$ & $2(1-3)$ \\
Lang II & $2.72(0.497)$ & $2(1-3)$ \\
Titmus test & $2.88(0.385)$ & $2(1-3)$ \\
Synoptophore & $16.98(6.523)$ & $29(5-34)$ \\
\hline
\end{tabular}

$\mathrm{NPC}=$ near point of convergence measured in centimeters; Lang I and $\mathrm{II}=$ measures ability to see $0 / 3,1 / 3,2 / 3$ or $3 / 3$ figures; Titmus test $=$ measures ability to see $0 / 3,1 / 3,2 / 3$ or $3 / 3$ figures; synoptophore $=$ measures fusion span in degrees $\mathrm{TR}=$ total range; $\mathrm{M}=$ mean; $\mathrm{SD}=$ standard deviation

Table 3. Descriptive data on NPC, stereo tests (Lang I, Lang II, Titmus test) and synoptophore at third visit

\begin{tabular}{|l|l|l|}
\hline Variable & M (SD) & TR (min, max) \\
\hline NPC & $5.10(1.961)$ & $7(3-10)$ \\
Lang I & $2.80(0.606)$ & $3(0-3)$ \\
Lang II & $2.88(0.520)$ & $3(0-3)$ \\
Titmus test & $2.88(0.480)$ & $2(1-3)$ \\
Synoptophore & $17.88(7.542)$ & $34(4-38)$ \\
\hline
\end{tabular}

$\mathrm{NPC}=$ near point of convergence (measured in centimeters); Lang $\mathrm{I}$ and II = measure ability to see $0 / 3,1 / 3,2 / 3$ or $3 / 3$ figures; Titmus test $=$ measures ability to see $0 / 3,1 / 3,2 / 3$ or $3 / 3$ figures; synoptophore $=$ measures fusion span in degrees; $\mathrm{TR}=$ total range; $\mathrm{M}=$ mean; $\mathrm{SD}=$ standard deviation

ning of treatment. Mean values, standard deviation and total range methods of descriptive statistics were used to assess their distribution (Tables 1-3).

Analysis of variance ( $t$-test dependent variables and ANOVA) was used to analyze differences in con- 
Table 4. ANOVA of three repeated convergence measurements

\begin{tabular}{|l|l|l|l|l|}
\hline Measurement & Measurement & Standard deviation & $\begin{array}{l}\text { Mean difference } \\
(\mathrm{M} 1-\mathrm{M} 2)\end{array}$ & $\begin{array}{l}\text { Level of significance } \\
(\mathrm{p})\end{array}$ \\
\hline \multirow{2}{*}{1} & 2 & 0.388 & $4.84^{*}$ & 0.000 \\
\hline \multirow{2}{*}{2} & 3 & 0.421 & $6.06^{*}$ & 0.000 \\
\hline \multirow{2}{*}{3} & 1 & 0.388 & $-4.84^{*}$ & 0.000 \\
\cline { 2 - 5 } & 3 & 0.289 & $1.22^{*}$ & 0.000 \\
\hline
\end{tabular}

${ }^{*} \mathrm{p}<0.05$

Table 5. ANOVA of three repeated Lang I stereo test measurements

\begin{tabular}{|l|l|l|l|l|}
\hline Measurement & Measurement & Standard deviation & $\begin{array}{l}\text { Mean difference } \\
(\mathrm{M} 1-\mathrm{M} 2)\end{array}$ & $\begin{array}{l}\text { Level of significance } \\
(\mathrm{p})\end{array}$ \\
\hline \multirow{2}{*}{1} & 2 & 0.116 & $-0.98^{*}$ & 0.000 \\
\hline \multirow{2}{*}{2} & 3 & 0.117 & $-1.18^{*}$ & 0.000 \\
\hline \multirow{2}{*}{3} & 1 & 0.116 & $0.98^{*}$ & 0.000 \\
\cline { 2 - 5 } & 3 & 0.081 & -0.20 & 0.051 \\
\hline
\end{tabular}

*p $<0.05$

Table 6. ANOVA of three repeated Lang II stereo test measurements

\begin{tabular}{|l|l|l|l|l|}
\hline Measurement & Measurement & Standard deviation & $\begin{array}{l}\text { Mean difference } \\
(\mathrm{M} 1-\mathrm{M} 2)\end{array}$ & $\begin{array}{l}\text { Level of significance } \\
(\mathrm{p})\end{array}$ \\
\hline \multirow{2}{*}{1} & 2 & 0.105 & $-0.68^{*}$ & 0.000 \\
\hline \multirow{2}{*}{2} & 3 & 0.096 & $-0.84^{*}$ & 0.000 \\
\hline \multirow{2}{*}{3} & 1 & 0.105 & $0.68^{*}$ & 0.000 \\
\cline { 2 - 5 } & 3 & 0.072 & -0.16 & 0.093 \\
\cline { 2 - 5 } & 1 & 0.096 & $0.84^{*}$ & 0.000 \\
\hline
\end{tabular}

* $\mathrm{p}<0.05$

vergence, fusion range and stereovision among the three points of measurement. CI was determined by measuring NPC; stereovision was measured with stereo tests (Lang I and II and Titmus tests), while fusion range was tested on synoptophore. A level of 0.05 was considered significant.

Most of the participants were boys $(n=41 ; 82 \%)$ and the mean duration of eye exercises was 8.82 (SD 5.09) months.

To determine statistically significant difference in convergence among the first, second and third measure- ments, we used the analysis of variance for repeated measurements. The results showed that each measurement significantly differed from the other two $(\mathrm{p}<0.05)$. The difference between the first and second measurement $\left(M_{1}-M_{2}=4.84, p<0.05\right)$, as well as between the first and third measurement $\left(\mathrm{M}_{1}-\mathrm{M}_{2}=6.06, \mathrm{p}<0.05\right)$ was significant. Furthermore, we found a statistically significant difference in the results between the second and third measurement $\left(\mathrm{M}_{1}-\mathrm{M}_{2}=1.22, \mathrm{p}<0.05\right)$. For all the participants with data available for three time points, the mean NPC $(11.6 \mathrm{~cm}, \mathrm{SD}=3.431$; range $4-19 \mathrm{~cm})$ at 


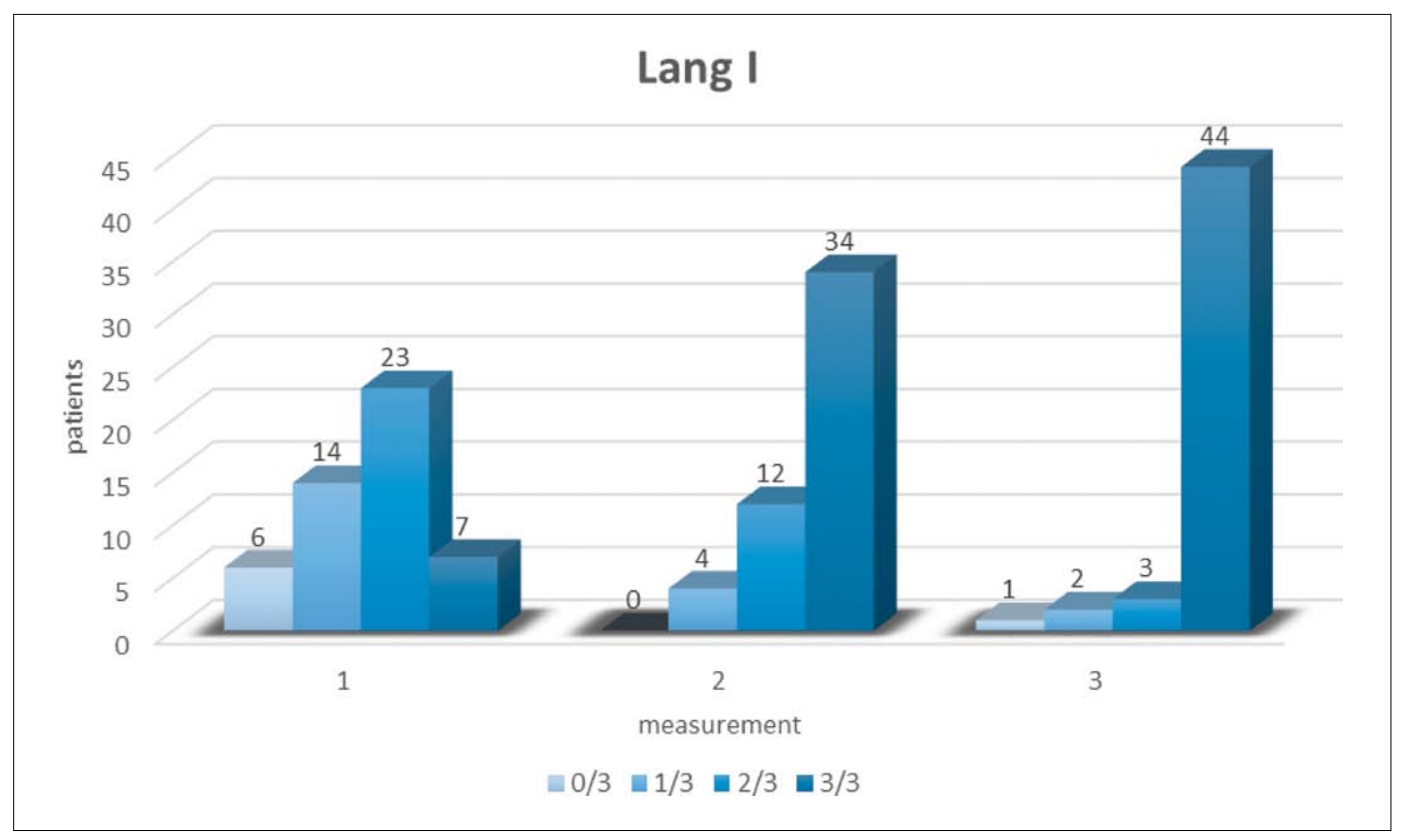

Fig. 1. Lang I test: number of patients seeing 0, 1, 2 or 3 figures.

$0 / 3=$ sees no figure; $1 / 3=$ sees one figure; $2 / 3=$ sees two figures; $3 / 3=$ sees three figures

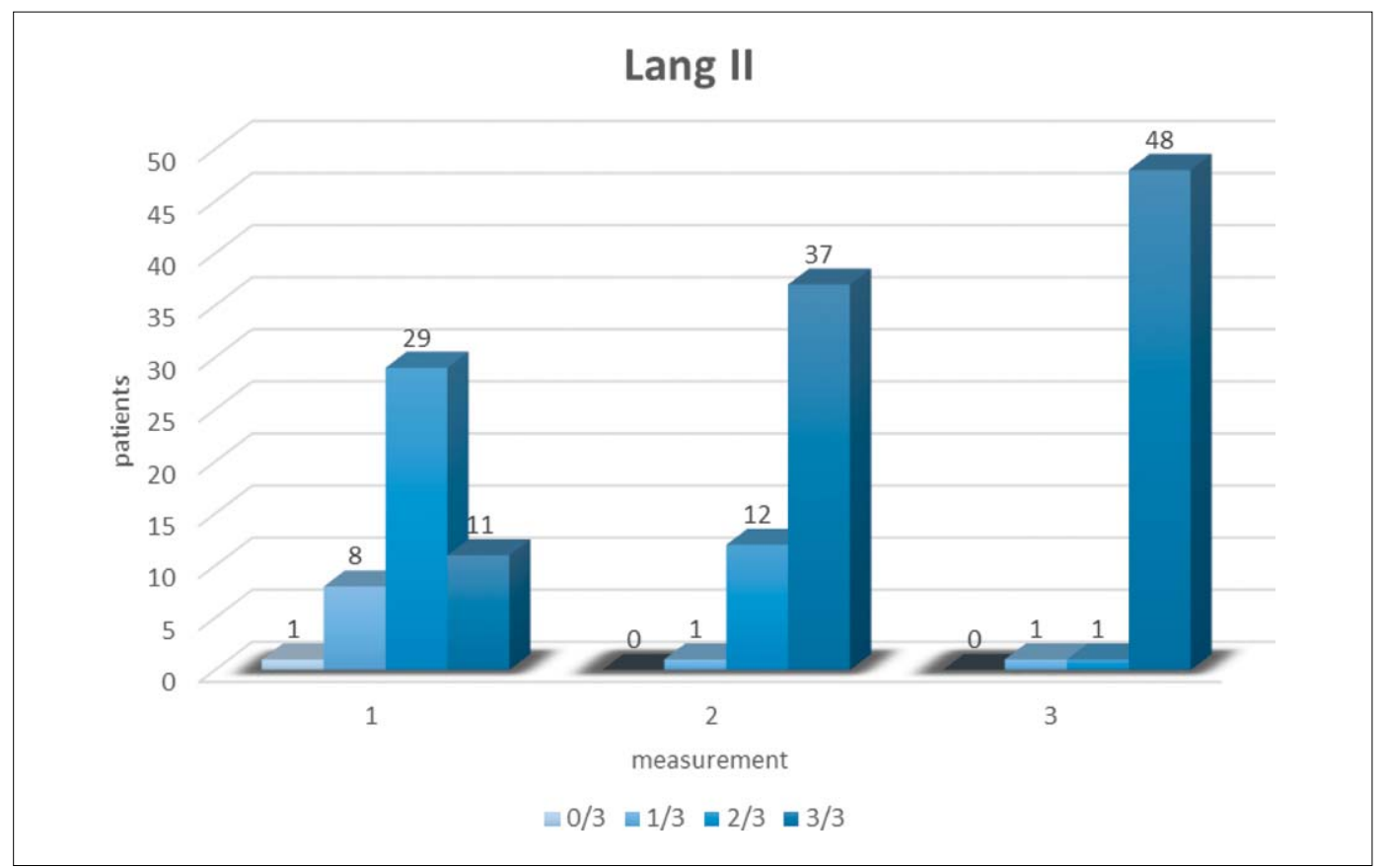

Fig. 2. Lang II test: number of patients seeing 0, 1, 2 or 3 figures.

$0 / 3=$ sees no figure; $1 / 3=$ sees one figure; $2 / 3=$ sees two figures; $3 / 3=$ sees three figures

the beginning of therapy compared to the mean NPC at final examination $(5.10 \mathrm{~cm}, \mathrm{SD}=1.961$; range $3-10 \mathrm{~cm})$ improved significantly $\left(\mathrm{M}_{1}-\mathrm{M}_{2}=1.22, \mathrm{p}<0.05\right)$. In other words, there was statistically significant improvement of convergence at three and six months of orthoptic therapy initiation (Table 4). 
Table 7. ANOVA of three repeated Titmus $A B C$ measurements

\begin{tabular}{|l|l|l|l|l|}
\hline Measurement & Measurement & Standard deviation & $\begin{array}{l}\text { Mean difference } \\
(\mathrm{M} 1-\mathrm{M} 2)\end{array}$ & $\begin{array}{l}\text { Level of significance } \\
(\mathrm{p})\end{array}$ \\
\hline \multirow{2}{*}{1} & 2 & 0.120 & $-0.64^{*}$ & 0.000 \\
\cline { 2 - 5 } & 3 & 0.127 & $-0.64^{*}$ & 0.000 \\
\hline \multirow{2}{*}{3} & 1 & 0.120 & $0.64^{*}$ & 0.000 \\
\cline { 2 - 5 } & 3 & 0.057 & 0.00 & 1.000 \\
\cline { 2 - 5 } & 1 & 0.127 & $0.64^{*}$ & 0.000 \\
\hline
\end{tabular}

${ }^{*} \mathrm{p}<0.05$

Table 8. ANOVA of three repeated synoptophore measurements

\begin{tabular}{|l|l|l|l|l|}
\hline Measurement & Measurement & Standard deviation & $\begin{array}{l}\text { Mean difference } \\
(\mathrm{M} 1-\mathrm{M} 2)\end{array}$ & $\begin{array}{l}\text { Level of significance } \\
(\mathrm{p})\end{array}$ \\
\hline \multirow{3}{*}{1} & 2 & 0.884 & $-5.84^{*}$ & 0.000 \\
\hline \multirow{2}{*}{2} & 3 & 1.062 & $-6.74^{*}$ & 0.000 \\
\hline \multirow{2}{*}{3} & 1 & 0.884 & $5.84^{*}$ & 0.000 \\
\cline { 2 - 5 } & 3 & 0.682 & -0.90 & 0.580 \\
\hline & 1 & 1.062 & $6.74^{*}$ & 0.000 \\
\cline { 2 - 5 } & 2 & 0.682 & 0.90 & 0.580 \\
\hline
\end{tabular}

${ }^{*} \mathrm{p}<0.05$

Table 2 shows data on differences among the three points of measurement in Lang I stereo test, yielded by the analysis of variance (ANOVA) for repeated measurements. There was a statistically significant difference between the first and second measurement $(p<0.05)$, but no such difference between the second and third measurement ( $p>0.05)$.

Results of the analysis of variance for three Lang II stereo test measurements are shown in Table 3. There was a statistically significant difference between the first and second measurement $(p<0.05)$, whereas there was no such difference between the second and third measurement $(p>0.05)$. Accordingly, the values of Lang I and II tests improved significantly after treatment and were $\mathrm{M}=1.62$ (SD 0.878) and $\mathrm{M}=2.04$ ( $\mathrm{SD}=0.699$ ) for Lang I and Lang II, respectively, at therapy initiation versus $\mathrm{M}=2.80$ (SD 0.606) and $\mathrm{M}=2.88$ (SD 0.520) $(\mathrm{p}<0.05)$ for Lang I and Lang II, respectively, at final visit, indicating considerably better results in binocular vision at the end of therapy than at the first visit (Tables 5 and 6).

Figures 1 and 2 clearly illustrate improvements in Lang I and Lang II, showing better results at second measurement through enhanced capacity of depth perception; each time participants saw more figures, which implicated better stereovision. Value $0 / 3$ implicates inability to see any figure; value $1 / 3$ seeing one figure out of three; value $2 / 2$ seeing two figures out of three; and value $3 / 3$ seeing all three figures, each with more depth perception and more difficult to see.

Differences in the means $\left(\mathrm{M}_{1}-\mathrm{M}_{2}\right)$ with standard deviations and levels of significance $(p)$ for Titmus $\mathrm{ABC}$ test on three measurements are shown in Table 7. The results recorded on the first measurement showed a statistically significant difference from the second $\left(\mathrm{M}_{1}-\mathrm{M}_{2}=-0.64, \mathrm{p}<0.05\right)$ and third measurement $\left(\mathrm{M}_{1}-\mathrm{M}_{2}=-0.64 ; \mathrm{p}<0.05\right)$, suggesting improvement of stereovision after three months. As in other tests of binocular vision (Lang I and II), there was no statistically significant difference in the results recorded on the second and third measurement; in fact, the results were identical $(p>0.05)$ (Table 7).

To test difference in fusion range measured on synoptophore in our patients, we performed the analysis of variance of three repeated measurements. The results showed a statistically significant difference be- 


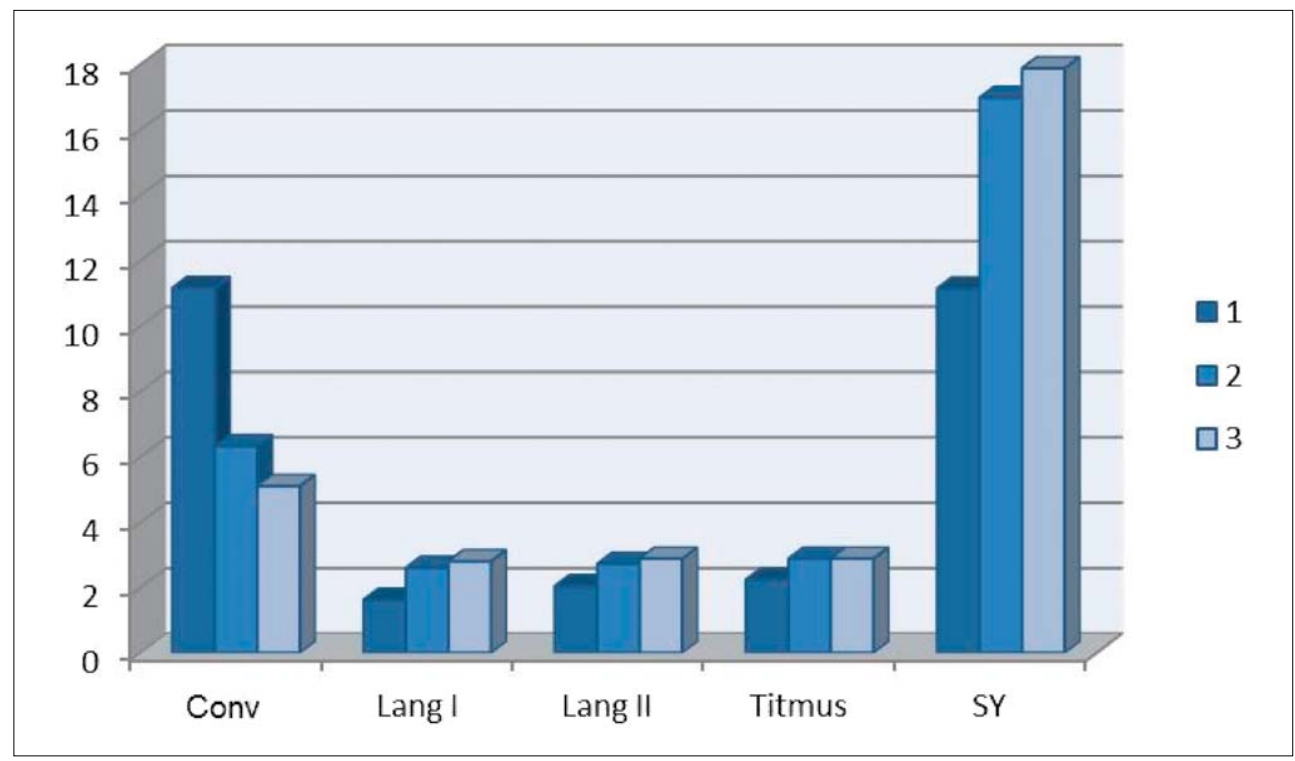

Fig. 3. Near point of convergence, Lang I, Lang II, Titmus test and fusion span on synoptophore (SY) before and after orthoptic therapy (measurements 1, 2 and 3).

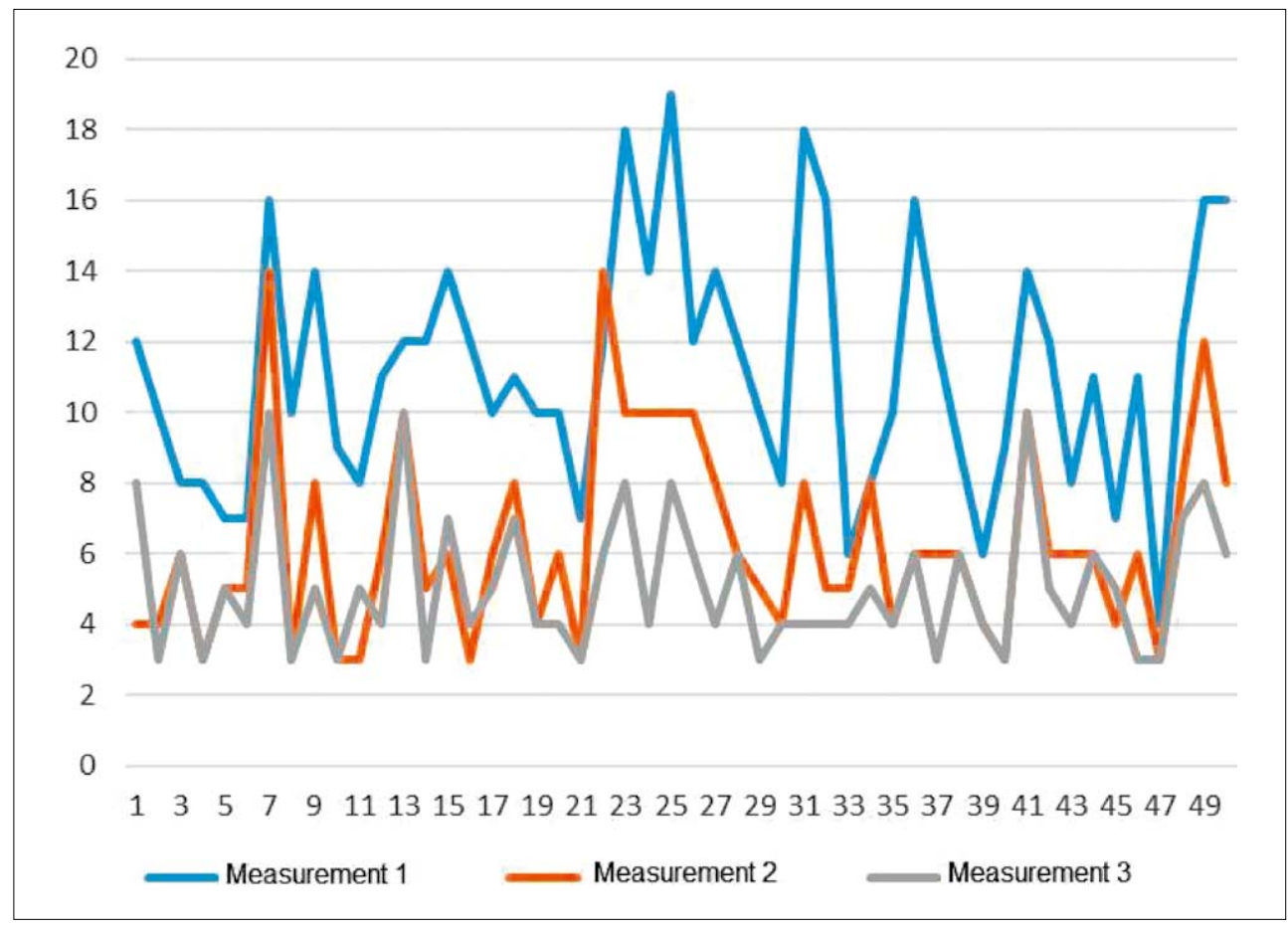

Fig. 4. Near point of convergence before therapy, and three and six months after therapy.

tween the first and second measurement $\left(\mathrm{M}_{1}-\mathrm{M}_{2}=-\right.$ $5.84, \mathrm{p}<0.05)$, whereas the results recorded on the second and third measurement showed no such difference ( $p>0.05)$. The mean value of fusion range measured on synoptophore was $\mathrm{M}=11.14$ ( $\mathrm{SD}$ 6.395), total range
0-32 at the beginning and $\mathrm{M}=17.88$, (SD 67.542), range 4-38 at the end. Differences in the mean fusion range between the beginning of therapy and final examination were also significant $(\mathrm{p}<0.05)$. It means that the fusion range was significantly improved after three 
months and remained at the same level in the next three-month period (Table 8).

The initial measurement was taken before therapy, second after three months and third after six months of therapy. The results showed statistically significant improvement in all five values examined (NPC, Lang I, Lang II, Titmus test and synoptophore) after three and six months; however, we found no statistically significant difference in the values between second and third measurements, except for CI where the difference between the second and third measurement was significant, suggesting that improvement occurred after the first three months and remained more or less constant (Figs. 3 and 4).

\section{Discussion}

According to multiple studies ${ }^{34-36}$, orthoptic therapy improves NPC, which itself enhances improvement in binocular potential (stereovision) ${ }^{37}$. However, the impact of eye exercises on children who have both ADHD and CI has not yet been examined. Since CI is a treatable disorder, therapy with orthoptic exercises may help diminish visual symptoms in patients with ADHD and CI.

For nearly 70 years, orthoptic specialists and pediatric ophthalmologists use eye exercises in their practice. Various options of vision therapy or vision training are available, both simple, home-based exercises or intensive, clinic-based methods.

The Convergence Insufficiency Treatment Trial (CITT) Group designed a large multicenter trial comparing the effects of different treatment procedures on $\mathrm{CI}$, a condition where most professionals agree that exercises are effective ${ }^{24}$. Although proving that children receiving office-based therapy had better outcome compared to home-based methods, there was a lack of strong evidence quantifying the effectiveness of each therapy. Further studies ${ }^{36}$ concluded that consensus on the most appropriate home-based convergence exercise was still lacking due to different opinions regarding the exact procedure of pencil push-ups and their effectiveness in comparison to other home-based exercises. In pencil push-ups, the aim should be to increase both the phasic and tonic control of convergence and therefore the convergence sustenance should also be practiced ${ }^{36}$. The pencil push-ups, as advised in the article by Scheiman et al. from the CITT Group, did not stress the role of convergence sustenance ${ }^{20}$. In 2006, Aziz et al. demonstrated in their study that deficiencies in NPC, fusion convergence and asthenopic symptoms responded well to orthoptic exercises, having a high symptomatic cure rate of $83.3 \% \%^{37}$.

It is evident that CI is treated successfully with various combinations of orthoptic exercises. Since CI is a comorbid disorder in some children with ADHD, it could also aggravate certain symptoms that are almost omnipresent in children with attention deficit while performing near work. It has also been noticed that children with attention deficit, due to the lack of concentration, may appear as to have CI. Since we found a high incidence of $\mathrm{CI}$ in children with $\mathrm{ADHD}$ (35.6\%), we decided to examine the influence of orthoptic exercises on ADHD children and adolescents also having CI.

The results of our study showed that NPC, as well as stereovision, improved after orthoptic therapy in children diagnosed with both ADHD and CI. Our results showed statistically significant enhancement in all five values examined (NPC, Lang I, Lang II, Titmus test and synoptophore) three and six months after therapy initiation; however, we found no statistically significant difference in these values between the second and third measurement, suggesting that improvement occurred after the first three months and remained almost more or less constant. Furthermore, our results showed orthoptic exercises to be effective in children and adolescents with ADHD who were diagnosed with CI.

The question of whether treatment of CI would diminish visual symptoms in children with ADHD had intrigued us; although it is apparently common sense that it does, it has not been studied before and proved until now.

\section{Conclusion}

The results of our study showed that treatment of CI with orthoptic exercises was efficient in children and adolescents diagnosed with ADHD in spite of their concentration difficulties and attention deficit. Since eye exercises effectively reduce symptoms of CI and also improve stereovision, we suppose that visual therapy may contribute to the treatment of ADHD. It could be advisable for children diagnosed with ADHD, 
especially with the Predominantly Inattentive Type according to DSM-V criteria, to have thorough ophthalmologic evaluation with detailed observation of NPC and stereovision. Furthermore, it may imply that successful therapy of CI could possibly improve some symptoms of ADHD. Since CI can aggravate attention while performing near work, it is sound to suppose that by improving convergence, attention would be improved as well. Further studies are needed to determine whether visual therapy is effective in a larger number of participants and which modality of therapy for $\mathrm{CI}$ is most effective for patients with ADHD and CI. It would help determine whether improvement of attention and concentration is possible after the treatment of CI.

This study could serve as a base trial for further research into the connection of attention deficit and CI.

\section{References}

1. Stubbe DE. Attention deficit hyperactivity disorder. In: Cheng K, Myers KM, editors. Child and Adolescent Psychiatry; The Essentials. Philadelphia, USA: Lippincott Williams and Wilkins, 2005; p. 469-79.

2. Spetie L, Arnold EL. Attention deficit hyperactivity disorder. In: Martin A, Volkmar FR, editors. Lewis's Child and Adolescent Psychiatry, A Comprehensive Textbook, $4^{\text {th }}$ edn. Philadelphia, USA: Wolters Kluwer, Lippincot Williams \& Wilkins, 2007; p. 430-54.

3. American Psychiatric Association. Diagnostic and Statistical Manual of Mental Disorders, $5^{\text {th }}$ edn. Washington, DC: American Psychiatric Press, 2013.

4. Karlović D, Zoričić Z, Buljan D, Crnković D, Martinac M. Correspondence between DSM IV attention deficit/hyperactivity disorder and ICD 10 hyperkinetic disorder in a Croatian sample. Acta Clin Croat. 2002;42:239-45.

5. Zametkin AJ, Nordahl TE, Gross M, King AC, Semple WE, Rumsey J, et al. Cerebral glucose metabolism in adults with hyperactivity of childhood onset. N Engl J Med. 1990;323: 1361-6.

6. Hynd GW, Semrud-Clikeman M, Lorys AR, Novey ES, E1iopulos D. Brain morphology in developmental dyslexia and attention deficit disorder/hyperactivity. Arch Neurol. 1990;47: 919-26.

7. DiMaio S, Grizenko N, Joober R. Dopamine genes and attention-deficit hyperactivity disorder: a review. J Psychiatry Neurosci. 2003;28:27-38.

8. Biederman J. Attention-deficit/hyperactivity disorder: a selective overview. Biol Psychiatry. 2005;57:1215-20.

9. Cantwell DP. The Hyperactive Child. New York: Spectrum, 1975.
10. Duke-Elder S, Wybar K. Ocular motility and strabismus. In: Duke-Elder S, editor. System of Ophthalmology. Vol. 6. St. Louis: Mosby, 1973; p. 204-6.

11. Pickwell LD, Hampshire R. The significance of inadequate convergence. Ophthalmic Physiol Opt. 1981;1:13-8. [PubMed: 7339524]

12. Borsting E, Rouse MW, Deland PN, Hovett S, Kimura D, Park $\mathrm{M}$, Stephens B. Association of symptoms and convergence and accommodative insufficiency in school-age children. Optometry. 2003;74:25-34. [PubMed: 12539890]

13. Letourneau JE, Lapierre N, Lamont A. The relationship between convergence insufficiency and school achievement. Am J Optom Physiol Opt. 1979;56:18-22. [PubMed: 484699]

14. Letourneau J, Ducic S. Prevalence of convergence insufficiency among elementary school children. Can J Optom. 1988;50: 194-7.

15. Rouse MW, Borsting E, Hyman L, Hussein M, Cotter SA, Flynn M, Scheiman M, Gallaway M, De Land PN, the Convergence Insufficiency and Reading Study (CIRS) group. Frequency of convergence insufficiency among fifth and sixth graders. Optom Vis Sci. 1999;76:643-9. [PubMed: 10498006]

16. Passmore JW, MacLean F. Convergence insufficiency and its managements: an evaluation of 100 patients receiving a course of orthoptics. Am J Ophthalmol. 1957;43(3):448-56.

17. Mould WL. Recognition and management of atypical convergence insufficiency. J Pediatr Ophthalmol. 1970;7:212-4.

18. Ćelić M, Dorn V. Strabizam i nistagmus. Zagreb: Medicinska naklada, 2004; p. 182. (in Croatian)

19. Scheiman M, Cotter S, Rouse M, Mitchell GL, Kulp M, Cooper J, Borsting E. Randomised clinical trial of the effectiveness of base-in prism reading glasses versus placebo reading glasses for symptomatic convergence insufficiency in children. Br J Ophthalmol. 2005;89:1318-23. [PubMed: 16170124]

20. Scheiman M, Mitchell GL, Cotter S, Kulp MT, Cooper J, Rouse M, Borsting E, London R, Wensveen J. A randomized clinical trial of vision therapy/orthoptics versus pencil pushups for the treatment of convergence insufficiency in young adults. Optom Vis Sci. 2005;82:583-95. [PubMed: 16044063]

21. Gallaway M, Scheiman M, Malhotra K. The effectiveness of pencil pushups treatment for convergence insufficiency: a pilot study. Optom Vis Sci. 2002;79:265-7.

22. Convergence Insufficiency Treatment Trial (CITT) Study Group. Randomized clinical trial of treatments for symptomatic convergence insufficiency in children. Arch Ophthalmol. 2008;126:1336-49. [PubMed: 18852411]

23. Convergence Insufficiency Treatment Trial (CITT) Study Group. The convergence insufficiency treatment trial: design, methods, and baseline data. Ophthalmic Epidemiol. 2008; 15:24-36. [PubMed: 18300086]

24. Convergence Insufficiency Treatment Trial Study Group. Long-term effectiveness of treatments for symptomatic convergence insufficiency in children. Optom Vis Sci. 2009;86: 1096-103. [PubMed: 19668097] 
25. Birnbaum MN, Soden R, Cohen AH. Efficacy of vision therapy for convergency insufficiency in an adult male population. $J$ Am Optom Assoc. 1999;70:225-32.

26. Rawstron JA, Burley CD, Elder MJ. A systematic review of the applicability and efficacy of eye exercises. J Pediatr Ophthalmol Strabismus. 2005 Mar 1;42(2):82-8.

27. Lavrich JB. Convergence insufficiency and its current treatment. Curr Opin Ophthalmol. 2010;21(5):356-60.

28. Scheiman M, Gwiazda J, Li T. Non-surgical interventions for convergence insufficiency. Cochrane Database Syst Rev. 2011; 3:CD006768

29. Scheiman M, Rouse M, Kulp MT, et al. Treatment of convergence insufficiency in childhood: a current perspective. Optom Vis Sci. 2009;86(5):420-8.

30. Birnbaum MH, Soden R, Cohen AH. Efficacy of vision therapy for convergence insufficiency in an adult male population. $J$ Am Optom Assoc. 1999;70:225-32.

31. Granet DB, Gomi CF, Ventura R, et al. The relationship between convergence insufficiency and ADHD. Strabismus. 2005;13(4):163-8.
32. Decarlo D, Swanson M, McGwin G, Visscher K, Owlsey C. ADHD and vision problems in the national survey of children's health, Optom Vis Sci. 2016 May;93(5):459-65.

33. Sun Haeng Lee, Moon B-J, Cho HG. Improvement of vergence movements by vision therapy decreases K-ARS scores of symptomatic ADHD children. J Phys Ther Sci. 2014 Feb; 26(2):223-7.

34. Harinder Singh Sethi, Rohit S, Pradeep S. Home exercises for convergence insufficiency in children. Arch Ophthalmol. 2006;124(2):287. doi:10.1001/archopht.124.2.287-a

35. Chavasse F. Worth's Squint. $7^{\text {th }}$ edn. London: Balliere Tindall \& Cox, 1939; p. 514.

36. Griffin J, Grisham J. Binocular Anomalies: Diagnosis and Vision Therapy. Boston, MA: Butterworth-Heinemann, 2002.

37. Aziz S, Cleary M, Stewart HK, Weir CR. Are orthoptic exercises an effective treatment for convergence and fusion deficiencies? Strabismus. 2006 Dec;14(4):183-9.

\section{IMAJU LI ORTOPTIČKE VJEŽBE UTJECAJ NA DJECU I ADOLESCENTE S POREMEĆAJEM NEDOSTATKA PAŽNJE S HIPERAKTIVNOŠĆU I ISTODOBNO INSUFICIJENCIJOM KONVERGENCIJE?}

\section{B. Dawidowsky, B. Cerovski, A. Klobučar i K. Dawidowsky}

Cilj je bio ustanoviti imaju li ortoptičke vježbe koje smanjuju simptome insuficijencije konvergencije (IK) i unaprjeđuju stereovid utjecaj i na djecu koja uz dijagnozu IK imaju i poremećaj pažnje s hiperaktivnošću (attention deficit/hyperactivity disorder, ADHD). Ortoptička terapija je provedena na 50 djece s ADHD-om i istodobno dijagnosticiranom IK. Terapija je uključivala vježbe kod kuće i vježbe u ortoptičkom kabinetu na sinoptoforu. Mjerena je bliza točka konvergencije (BTK) i binokularni vid na stereotestovima i sinoptoforu prije, tijekom i poslije terapije. Ispitanici su pokazali značajno poboljšanje $(p<0,05)$ u BTK i testovima binokularnog vida nakon ortoptičkih vježbi. Pronađena je statistički značajna korelacija između poboljšanja BTK i stereovida (Lang I.), što upućuje na zaključak da je poboljšanje binokularnog vida moguće u djece i adolescenata s IK i ADHD-om. Prema rezultatima našeg istraživanja ortoptička terapija dovodi do poboljšanja BTK i istodobnog poboljšanja binokularnog vida u djece s ADHD-om i IK. Kako unaprjeđenje binokularnog vida ima pozitivan učinak na kvalitetu rada na blizinu i istodobno smanjuje nespecifične vidne simptome koje često imaju djeca s ADHD-om i IK, moguće je da ortoptička terapija može utjecati i na poboljšanje koncentracije, što mislimo da je razumno dalje ispitati. Potrebna su daljnja ispitivanja koja bi utvrdila utječu li ortoptičke vježbe i kako na koncentraciju i pažnju.

Ključne riječi: Poremećaj nedostatka pažnje s hiperaktivnošću; Očna pokretljivost, poremé́aji; Vid, binokularni 